\title{
Corporate Governance Structure and Performance in the Tourism Industry in the COVID-19 Pandemic: An Empirical Study of Chinese Listed Companies in China
}

\author{
Shanyue Jin ${ }^{1}$, Yuying Gao ${ }^{2}$ and Shufeng (Simon) Xiao ${ }^{3, *}$ (I) \\ 1 College of Business, Gachon University, Seongnam 13120, Korea; jsyrena0923@gachon.ac.kr \\ 2 College of Economics and Management, Pingdingshan University, Pingdingshan 467000, China; \\ gyy3990@outlook.com \\ 3 Division of Business Administration, Sookmyung Women's University, Seoul 04310, Korea \\ * Correspondence: bizsxiao@sookmyung.ac.kr
}

Citation: Jin, S.; Gao, Y.; Xiao, S. Corporate Governance Structure and Performance in the Tourism Industry in the COVID-19 Pandemic: An Empirical Study of Chinese Listed Companies in China. Sustainability 2021, 13, 11722. https://doi.org/ $10.3390 /$ su132111722

Academic Editor: Kisang Ryu

Received: 29 September 2021

Accepted: 21 October 2021

Published: 23 October 2021

Publisher's Note: MDPI stays neutral with regard to jurisdictional claims in published maps and institutional affiliations.

Copyright: (C) 2021 by the authors. Licensee MDPI, Basel, Switzerland. This article is an open access article distributed under the terms and conditions of the Creative Commons Attribution (CC BY) license (https:/ / creativecommons.org/licenses/by/ $4.0 /)$.

\begin{abstract}
All industries around the world have been greatly impacted by the 2019 COVID-19 outbreak. China's tourism market was almost suspended. Tourism enterprises generally face difficulties in the form of low capital turnover and increased operating pressure, and the overall tourism industry is showing a downturn in its development. In this study, we construct a quasi-natural experiment with the COVID-19 pandemic in public health emergencies using a propensity score matching difference in differences model (PSM-DID) to match the treatment group of tourism enterprises and the control group of non-tourism enterprises. We empirically test that the COVID-19 pandemic has produced a more severe impact on the performance of tourism enterprises than other industries. Further analysis shows that given different enterprise equity natures, the characteristics of the board, supervision, and executive salary incentive levels, the COVID-19 pandemic has a heterogeneous impact on the operating performance of tourism enterprises.
\end{abstract}

Keywords: COVID-19; tourism; PSM-DID; corporate performance; corporate governance structure

\section{Introduction}

In late 2019, the occurrence of a major public health emergency, COVID-19, had a huge impact on social and economic life worldwide. Tourism is a highly environmentally sensitive industry, which is demonstrated by the fact that the development of tourism is inevitably influenced and constrained by a variety of internal and external factors, and is highly vulnerable to the impact and influence of internal and external emergencies, which can lead to serious recessions and landslides [1,2]. COVID-19 is extremely infectious and seriously harmful to society, and was listed as a public health emergency of international concern on 30 January 2020. Tourism (mainly catering, accommodation, and sightseeing experiences) is essentially a labor-intensive industry, and the gathering of tourists can easily increase the risk of infection. Given the control of the epidemic, people's home isolation and reduced unnecessary travel have led to a significant reduction in travel demand. At the same time, to effectively cut off the transmission route of the virus, travel agencies and tourism companies closed scenic spots, suspended tour groups, and stopped operations. The simultaneous reduction in both demand and supply caused a strong impact on the operations of the tourism industry. The World Tourism Organization [3,4] states that the COVID-19 pandemic has had a dramatic effect on the tourism economy, with complete disruption of tourism activities due to the closure of aircraft, hotels, and a ban on all travel as a result of the embargo policy, which has had a historically unprecedented impact on the travel and tourism industry. Listed tourism enterprises are the typical representatives and industry leaders of the development of the entire tourism industry. Their corporate governance modes and operational performance play a typical role in the development 
of the entire tourism industry. In the new environment, the governance and sustainable development of tourism companies has become an urgent problem in many countries around the world.

The corporate governance structure is an important factor affecting the operating efficiency of listed companies. A perfect corporate governance structure can reasonably allocate resources, reduce internal conflicts, improve governance capacity, and effectively improve the operating efficiency of listed companies $[5,6]$. However, in different economies and political backgrounds, the requirements of the corporate governance system are not identical [7], and many studies on corporate governance do not consider industry characteristics. Factors based on industry level, such as capital density, labor intensity, sensitivity to environmental fluctuations, corporate equity nature, and separation of ownership and management rights also influence corporate governance performance [8,9]. Tourism enterprises have different governance structures that distinguish them from other industries. Studies have argued that tourism enterprises generally have a single equity structure [10,11], board governance structure effectiveness deviation [6], lack of management compensation incentives, and other structures of corporate governance issues [12-14]. Given the impact of the sudden COVID-19 pandemic, it is particularly important to explore the development path for tourism enterprises to improve governance efficiency, maintain sustainable operation development, and enhance operational performance.

Therefore, this study first constructs a propensity score matching-difference in differences (PSM-DID) model with Chinese A-share non-financial listed companies from 2019 to 2020, and empirically analyzes the impact of the COVID-19 pandemic on the operating performance of the tourism industry compared to other industries. The results show that the impact of the COVID-19 pandemic has caused a more severe decline in the operations performance of the tourism industry. Further research on tourism enterprises found that the characteristics of enterprise governance structures have a moderating role in the above influence relationship. Among them, enterprises with state-owned equity, smaller boards of directors, and higher levels of executive salary incentives had less decline in corporate performance given the same impact.

The contributions of this paper are as follows. First, this study empirically examines the impact of the COVID-19 pandemic on the operation performance of tourism enterprises more thoroughly than other industries at the micro-firm level by using a PSM-DID model. Second, this study further explores the moderating effects of the above differential corporate governance factors on the business performance of tourism enterprises impacted by COVID-19, from four perspectives: enterprise equity characteristics, board structure, supervision, and executive salary incentives, proving that a well-developed corporate governance structure can mitigate the impact of the pandemic on the economy during public health emergencies and provide a theoretical basis for research in related fields.

\section{Literature Review and Hypothesis}

\subsection{The Impact of COVID-19 on the Performance of Tourism Enterprises}

The "World Economic Situation and Prospects" in mid-2021 published by the U.N. Department of Economic and Social Affairs states that East Asia and Latin America ae doing better than expected despite the impact of the COVID-19. The report highlights that manufacturing-dependent economics are doing well both during the crisis and recovery, but there is little chance of a quick rebound in tourism. Tourism is expected to remain sluggish due to the slow lifting of international travel restrictions and concerns about large-scale infections of the mutant virus in many developing countries [15].

According to the 2020 Statistical Bulletin on National Economic and Social Development of the People's Republic of China, China's gross domestic product in 2020 was 1555.87 billion US dollars, up 2.3 percent over the previous year. However, the growth rate has decreased significantly compared to the same period in 2019, with the tertiary industry, which is represented by the service industry, falling the most. 
The added value of information transmission, software and information technology services was 581.18 billion US dollars, up 16.9 percent over the previous year, and the added value of transportation, warehousing and postal services was 636.48 billion US dollars, up 0.5 percent over the previous year. However, value added to accommodation and restaurant businesses which are closely related to tourism dropped $13.1 \%$ to 244.58 billion US dollars [16].

According to the latest forecast released by the UN World Tourism Organization (UNWTO), the number of international tourists affected by COVID-19 will drop from $58 \%$ to $78 \%$ in 2020 from the previous year, with economic losses of USD 910 billion to USD 1.2 trillion, affecting 100 million to 120 million jobs directly related to tourism [17]. According to the sampling survey results of the 2020 Domestic Tourism Data issued by the Ministry of Culture and Tourism of the People 's Republic of China, affected by the COVID-19 pandemic, the number of domestic tourists in 2020 was 2.879 billion yuan, a decrease of 3.022 billion yuan, and $52.1 \%$ from the same period in 2019. Tourism revenue was 2.23 trillion yuan, down 3.50 trillion yuan, and $61.1 \%$ from the same period in 2019. In the first quarter of 2020, China's tourism industry appeared in a blank period, with organized tourism activities stopped comprehensively, and the self-service tourism market shrank significantly. Global tourism consumption dropped sharply, and a large number of tourism orders were canceled, leading to enterprises increasing cash flow pressure and mass employee turnover in tourism-related companies. The tourism industry experienced an unprecedented capital chain shortage, and some small- and medium-sized tourism enterprises went bankrupt as a result of the pandemic, while some other related enterprises also faced operating difficulties, including survival crises [18]. The rapid development of COVID-19 in late 2019 had an unprecedented impact on all industries in China. China, which is rich in tourism resources, has hit hard. The tourism industry, as an external environmentally sensitive industry, has suffered a more serious impact than other industries. In view of the above analysis, the following assumptions are made.

Hypothesis 1 (H1). The impact of COVID-19 has caused a more serious decline in tourism corporate performance than in other industries.

Hypothesis 1 (H1a). The impact of COVID-19 has caused a more serious decline in the return on total assets of tourism enterprises than in other industries.

Hypothesis 1 (H1b). The impact of COVID-19 has caused a greater decline in the growth rate of tourism enterprises than in other industries.

\subsection{The Heterogeneity of the Governance Structure of Tourism Enterprises in Regulating Corporate Performance}

The corporate governance structure is one of the important factors affecting the operating efficiency of listed tourism enterprises. A well-established corporate governance structure can reasonably allocate resources, reduce internal conflicts, and improve governance capacity, thus effectively improving the operating efficiency of listed companies [8]. Drawing on the studies of Core [19], Claessens [20], Bebchuk et al. [21], and Peng. et al. [10], the moderating role of corporate governance structure in the impact of the new crown pneumonia epidemic on firms' business performance is analyzed in terms of corporate equity characteristics, board characteristics, supervision, and executive compensation incentives.

\subsubsection{Nature of Enterprise Equity}

For listed companies with a high proportion of state-owned shares, their actual controllers or ultimate controllers are government agencies, state-owned asset management companies, state-owned asset control companies, and group companies held on behalf of the state. In relevant studies of Chinese corporate governance, enterprise equity properties are investigated as important investigation variables [22,23]. Previous studies on the 
characteristics of corporate equity believe that there is a negative relationship between the proportion of state-owned shares and company performance [22]. Research on Chinese enterprises shows that a high proportion of state-owned or state-owned holding enterprises generally have insider-control problems, low governance efficiency, are more prone to over-investment problems, and investment efficiency is significantly lower than that in private enterprises [24,25]. However, these studies ignore the heterogeneous effects of the nature of enterprise equity on corporate operating performance given different industry characteristics. Compared to other industries, the special characteristics of tourism are reflected in its government's dominance. Since the ownership of land in China is owned by the state and government departments at all levels dominate the allocation of resources, such as ownership, operation, development, and administrative approval of tourism resources, the initial stage of tourism development in China has a strong state attribute. After the COVID-19 outbreak, Ritchie and Jiang [26] noted that cooperation with governments at all stages of the tourism crisis helped enterprises escape the crisis faster. Given the impact of the COVID-19 outbreak, tourism enterprises are given the pressure of capital shortage, poor cash flow, and increased costs of epidemic prevention and control, but state-owned enterprises are more allowed to obtain policy support and small financing constraints than non-state-owned ones. Positive measures, such as government-backed bailouts, credit support, and financial subsidies can provide incentives to escape the crisis [27,28]. Therefore, this study proposes the following hypotheses.

Hypothesis 2 (H2). Compared with non-state-owned tourism enterprises, state-owned enterprises (SOEs) have decreased less in corporate performance given the impact of COVID-19.

Hypothesis 2 (H2a). Compared with non-state-owned tourism enterprises, SOEs have decreased less in corporate return on total assets given the impact of COVID-19.

Hypothesis $\mathbf{2}(\mathbf{H} \mathbf{2 b})$. Compared with non-state-owned tourism enterprises, SOEs have declined less in the growth rates of total operating revenue given COVID-19.

\subsubsection{Executive Compensation Incentives}

According to the expectancy theory [29], the higher the probability that managers expect to eventually achieve their goals, the more motivated they will be to manage the work, and as a result, corporate performance will increase and the enterprise will reward managers more and motivate them to continue their efforts, creating a virtuous circle, and thus reducing agency costs [22,30]. Listed companies' incentives for executives, including both compensation and equity incentives, and the former pay more attention to short-term incentives [31]. Most scholars believe that executive compensation incentives can improve corporate performance; that is, the greater the compensation incentives for executives, the better the company's performance [12,32-34]. In modern Chinese enterprises, the executive compensation system plays a key role in senior management incentives [35]. Because Chinese tourism listed companies have a high proportion of state-owned enterprises, their main executives are mostly appointed directly by the State-owned Assets Supervision and Administration Commission of the State Council (SASAC) or the central government. Their position is not a lifelong system and has a certain cycle liquidity, and their compensation level is determined by the state, so giving executives higher compensation incentives will be able to motivate them to serve the company better and improve company performance. The occurrence of COVID-19 has put great financial pressure on tourism enterprises so managers need to actively explore new development methods and innovative business models in the limited epidemic control policy range, while compensation incentives can play a strong incentive role in the short term to improve the performance of the enterprise. Based on this, the following hypotheses are proposed. 
Hypothesis 3 (H3). Tourism enterprises with higher levels of compensation incentives have less decline in corporate performance given the impact of COVID-19.

Hypothesis 3 (H3a). Tourism enterprises with higher levels of compensation incentives have less decline in their return on total assets given COVID-19.

Hypothesis $3 \mathbf{~ ( H 3 b ) . ~ T o u r i s m ~ e n t e r p r i s e s ~ w i t h ~ h i g h e r ~ l e v e l s ~ o f ~ c o m p e n s a t i o n ~ i n c e n t i v e s ~ h a v e ~ l e s s ~}$ decline in the growth rates of total operating revenue given COVID-19.

\subsubsection{Board Size}

Board size in previous studies was the main investigation variable in the field of corporate governance [36]. Based on the resource dependence theory, the board of directors mediates the relationship between the enterprise and its external environment [8]. Different scholars have drawn different conclusions about the relationship between board size and corporate performance. For non-tourism research, Coles et al. [37] and Dalton et al. [38] argue that a large board size obtains more critical information, brings more management experience, knowledge, and skills, and reduces external uncertainty, thus contributing to the improvement of the firm's financial performance. Instead, Yeh [8] argues that small board sizes have higher communication efficiency and promote decision-making and cooperation. An empirical analysis of the correlation between board size and company value based on Lipton and Lorsch [39], Jensen [40], Yermack [41], and Bebchuk et al. [21] shows that there is a negative relationship between board size and the company value expressed in Tobin $Q$, so they concluded that companies with smaller boards have a higher market capitalization. Nguyen et al. [42], citing the Australian listed company, demonstrated that the size of the board is negatively associated with corporate market capitalization. Mark et al. [43], De Andres et al. [44], and O'Connell and Cramer [45] argue that the expansion of the board size will increase the coordination cost within the company, and thus weaken the supervision and restraint function of the board. Therefore, the larger the board size, the worse the company's performance. The massive outbreak of COVID-19 has brought about a rapid impact on the environmentally sensitive tourism industry. In the face of emergencies, enterprises need a more efficient decision-making supervision and management mechanism to deal with the business stagnation caused by the epidemic emergency and the constantly adjusted policy guidance given the background of the normalization of the epidemic. In this context, tourism companies rely on management to make appropriate decisions in a changing environment to ensure competitiveness and cohesion [46,47]. Yeh and Trejos [48] note that it will be difficult for the company to maintain its advantage if the board of directors of the listed tourism companies fails to respond accordingly and promptly to a changing environment. To overcome the challenges of dynamic markets, a small board size is an appropriate governance structure for the success of tourism companies. Based on this, we propose the following hypotheses.

Hypothesis 4 (H4). The smaller the board size of tourism enterprises, the less the decline in corporate performance given COVID-19.

Hypothesis 4 (H4a). The smaller the board size of tourism enterprises, the less the decline in their return on total assets given COVID-19.

Hypothesis $4 \mathbf{( H 4 b )}$. The smaller the board size of tourism enterprises, the less the decline in the growth rates of total operating revenue given COVID-19.

\subsubsection{Size of the Supervisory Board}

The corporate governance structure mainly involves the three interests of management, the board of directors, and shareholders. The board of supervisors plays an internal super- 
visory role in the management activities of directors and senior managers and the finances of the company. Based on agency theory, the establishment of the board of supervisors is conducive to solving the agency problems caused by the separation of the two powers, but its impact on enterprise performance is still controversial. Li et al. [49] and Wang et al. [50], through an empirical analysis of the governance level of Chinese listed companies, argue that the governance level of the supervisory board is still relatively low, and the absence of the supervisory board is serious. The board of supervisors and independent directors can play a supervisory role in professional managers, but cannot effectively improve enterprise performance. Jensen [40] and Utama [51] believe that the efficiency of the board of supervisors beyond a certain scale declines, and an increase in the number of board members will lead to difficulties in communication, coordination, and decision-making, thus reducing their effectiveness and enterprise performance. The occurrence of COVID-19 has brought many uncertainties to enterprises, and the complex and changeable external environment brings great challenges to their operation and decision-making efficiency. Accordingly, this study proposes the following hypotheses.

Hypothesis 5 (H5). There is no impact of the size of the board of supervisors of tourism enterprises on corporate performance given the impact of COVID-19.

Hypothesis $\mathbf{5}$ (H5a). There is no impact of the size of the board of supervisors of tourism enterprises on the firm's total return on assets given the impact of COVID-19.

Hypothesis $\mathbf{5}(\mathbf{H} \mathbf{5 b})$. There is no impact of the size of the board of supervisors of tourism enterprises on the growth rates of total operating revenue given COVID-19.

\section{Research Design}

\subsection{Data and Samples}

The massive outbreak of COVID-19 in late 2019 has had a serious impact on all walks of life in China, with tourism taking the brunt. The main research object of this study is A-share listed tourism enterprises in Shanghai and Shenzhen in China. Therefore, this study intercepts the relevant data of listed companies from 2019 to 2020, and selects 287 listed tourism enterprises to establish a sample of the firm year. Among them, 144 tourism listed enterprises (due to data disclosure restrictions, 103 participate in the regression sample when testing the moderating effect of corporate governance structure), and a total of 143 non-tourism enterprises with similar characteristics are obtained by PSM nearest neighbor matching with asset-liability ratio, fixed assets, working capital ratio, total assets growth rate, and inventory turnover ratio as covariates. The financial data and enterprise governance-related data are derived from the China Stock Market \& Accounting Research Database (CSMAR). Considering the reliability of the research data and drawing on the processing methods of the data in the previous literature, this study treats the samples as follows: the financial sector is excluded, enterprises with missing values and ST, ST*, and PT listed companies are excluded; and enterprises that collapsed or went bankrupt during the study period are excluded. To reduce the effect of outlier fluctuations, the variables are Winsorized at the upper and lower $1 \%$ levels, and continuous variables are logarithmized to mitigate the interference of heteroskedasticity.

\subsection{Definition of the Variables}

3.2.1. Dependent Variable

The degree of enterprises using current resources to achieve their goals in the current environment is expressed as enterprise performance. The performance level reflects the current and future development of enterprises. Based on the financial management perspective, the return on total assets and the growth rate of total operating revenues are the core indicators for assessing firm performance, and for the credibility of the research analysis, 
this paper draws on Peng et al. [10], Yeh [8], and Aluchna and Kaminski [52] to select these two variables as the dependent variables for this paper. (1) Return on total assets (ROA) is the ratio of net profit to total assets to indicate the profitability of the enterprise; and (2) Growth rate of total operating revenue (Salesgro), that is, the total operating revenue of the current year minus the total operating revenue divided by the previous year's total operating revenue, to indicate the business growth status of the enterprise.

\subsubsection{Independent Variable}

In this study, COVID-19 is the independent variable (COVID-19) and the year of the COVID-19 outbreak is chosen as the cut-off point. That is, 2019, set COVID-19=0; 2020, set COVID-19 = 1 .

\subsubsection{Moderating Variables}

This study selects four variables from four perspectives: enterprise equity characteristics, board characteristics, supervision, and executive compensation incentives to examine the operating performance of tourism enterprises with different attributes in the context of COVID-19.

(1) Enterprise equity (Soe) classified according to the nature of enterprise equity in the CSMAR database using a dummy variable; when the enterprise is a state-owned enterprise, the value is 1 ; otherwise, it is 0 .

(2) Executive compensation incentives (Top3pay). Drawing on Kato and Long [35] and Li Muchun et al. [53], the logarithm of the total compensation of the top three executives with the highest amount is used.

(3) Board size (board); according to Al-Najjar [36] and Ntim et al. [35], board size is the total number of individuals included in the board of directors, and a larger value indicates a larger number of board members.

(4) Supervisory board size (supervisor). Drawing on Jensen [40] and Lars et al. [6] on corporate internal governance, the size of the supervisory board-the total number of individuals included in the supervisory board - is used as a proxy variable, and a larger value indicates a larger number of supervisory board members.

\subsubsection{Control Variable}

According to existing literature, this study adds a series of control variables that can affect the operating performance of an enterprise, including the enterprise total assets (Size), enterprise year (Age) and asset-liability ratio (Lev) [23], capital density (CD) [54], working capital ratio (Working CR), inventory turnover rate (Itr) and flow ratio (CR) [55], etc. Due to the large differences between different industries, the dummy variables are designed based on the industry classification guidelines for listed companies revised in 2012, which classify tourism listed companies into 4 major categories and 6 sub-industries. The industry effect (industry) is introduced in this study. If the enterprise belongs to this industry, the value is 1 ; otherwise, it is 0 (See Table 1 ). 
Table 1. Variables and measurement.

\begin{tabular}{|c|c|c|c|}
\hline & Variable & Name & Variable Measurement \\
\hline \multirow[b]{2}{*}{$\begin{array}{l}\text { Dependent } \\
\text { variable }\end{array}$} & ROA & Return on total assets & \multirow{2}{*}{$\begin{array}{c}\text { Net profit/total assets } \\
\text { (Total operating revenue for the current year - Total } \\
\text { operating revenue for the previous year)/Total } \\
\text { operating revenue for the previous year }\end{array}$} \\
\hline & Salesgro & Growth rate of total operating revenue & \\
\hline \multirow{5}{*}{$\begin{array}{c}\text { Independent } \\
\text { variable }\end{array}$} & COVID-19 & COVID-19 & \multirow{5}{*}{$\begin{array}{c}2019 \text { COVID- } 19=0 ; 2020 \text { COVID- } 19=1 \\
\text { State-owned enterprises }=1 ; \text { non-state-owned } \\
\text { enterprises }=0 \\
\text { Natural logarithm of the total compensation of the } \\
\text { top thee executives } \\
\text { Number of Board of Directors for the year } \\
\text { Number of Supervisory Board for the year }\end{array}$} \\
\hline & Soe & Nature of shareholding & \\
\hline & Top 3 pay & Executive compensation incentive & \\
\hline & Board & Board size & \\
\hline & Supervisory & Supervisory board size & \\
\hline \multirow{7}{*}{$\begin{array}{c}\text { Control } \\
\text { variables }\end{array}$} & Lev & Asset-liability ratio & Total liabilities/total assets \\
\hline & Size & Enterprise size & Natural logarithm of total assets \\
\hline & $\mathrm{CD}$ & Capital intensity & Ratio of total assets to operating income \\
\hline & Age & Company age & (Year of study - year of inception $)+1$ \\
\hline & WorkingCR & Working capital ratio & (Current assets - current liabilities)/Total assets \\
\hline & Itr & Inventory turnover rate & Operating costs/Closing balance of inventories \\
\hline & CR & Current ratio & Total current assets/Total assets \\
\hline
\end{tabular}

\subsection{Study the Model Design}

\subsubsection{Impact of the COVID-19 Outbreak on the Performance of Tourism Enterprises}

In this study, the PSM-DID method is used to estimate the significant impact of COVID-19 on the performance of tourism enterprises. The PSM-DID analysis is divided into two steps: propensity score matching (PSM) and difference in difference estimation (DID).

The PSM idea comes from the matching estimator, whose basic idea is to find enterprise $\mathrm{j}$ in the non-tourism control group to make so that it matches as closely as possible the observable variables of firm $i$ in the control group of tourism firms, when the individual characteristics of that enterprise depend entirely on the observable control variables on whether it is affected in the same way after the onset of the new crown epidemic, nontourism enterprise $j$, and tourism enterprise $i$ enterprise performance affected by COVID-19 outbreak similar probability. However, the direct matching method has limitations: too many identical variables mean matching in high-dimensional space and may encounter the problem of missing data. That is, it is difficult to find control group enterprises similar to the treatment group; however, too few matching variables may produce inappropriate control enterprises. The PSM method calculates the propensity score $\mathrm{p}$ according to the multidimensional matching index and matches the values according to the processing and control groups. The propensity score $\mathrm{p}$ is not only a one-dimensional variable, but also takes a value between 0 and 1 , which can better solve the above problem.

Since the public event variable tested in this article is COVID-19, its occurrence has had a great impact on the production and operation of various industries in the whole country, and it has a strong exogenous nature. The COVID-19 outbreak at the end of 2019 provided a quasi-natural experiment for this study, and the production and operation of Chinese enterprises were generally affected by the COVID-19 pandemic. To control the spread of COVID-19, China's strict quarantine and travel restrictions policies have made tourism operations more difficult, with a greater decline in operating performance than other industries. Tourism companies and other enterprises, which are more affected by the COVID-19 pandemic, have formed treatment and control groups. Because of the different initial conditions of the treatment and control groups, they vary greatly between enterprises, and the impact of public events on the enterprise will exist because of incomplete initial condition matching between the treatment group and the control group. To overcome the estimation bias of reducing the double difference method and more intuitively judge the 
significant impact of the COVID-19 outbreak on tourism, this study uses the PSM-DID model proposed by Rosenbaum and Donald [56] to estimate a double difference model with propensity score matching for the sample. Referring to Latorre et al. [57], Benzarti and Harju [58], effective variables are screened by Logit regression, and asset-liability ratio (Lev), fixed assets scale (LnFixed), working capital ratio (WorkingCR), total assets growth rate (Gro), and inventory turnover rate (Itr) are selected as nearest neighbor matching, while non-tourism enterprises with similar characteristics were selected as the control sample. To investigate whether the occurrence of COVID-19 had a more significant impact on tourism than other industries, the following difference-in-difference regression model is constructed in this study:

$$
\begin{gathered}
\text { Roa }_{i t}=\alpha_{0}+\alpha_{1} \text { Treat }_{i} \times \text { COVID-19 }_{t}+\alpha_{3} \text { Control }_{i t}+\mu_{i}+\varepsilon_{i t} \\
\text { Salesgro }_{i t}=\beta_{0}+\beta_{1} \text { Treat }_{i} \times \text { COVID-19 }_{t}+\beta_{2} \text { Control }_{i t}+\mu_{i}+\varepsilon_{i t}
\end{gathered}
$$

3.3.2. Heterogeneity Analysis of Corporate Governance Structures in the Tourism Industry in the Context of COVID-19

The COVID-19 outbreak has greatly affected all walks of life and caused a decline in business performance. However, the impacts of enterprises with different governance structures are different. This study further examines the heterogeneity of corporate governance structures to examine the different results of tourism enterprises with different types of governance structures in the aftermath of COVID-19. Learning from Claessens [20], Aluchna and Kaminski [52], Collins et al. [12], and other studies, we take the nature of the equity of enterprises, executive compensation incentive, board size, and supervisory board size as the moderating variables, to test the differential performance of tourism enterprises given the influence of the COVID-19 pandemic. The following moderating effect model is constructed:

$$
\begin{aligned}
& \text { ROA }_{i t}=\theta_{0}+\theta_{1} \text { COVID-19t }_{t}+\theta_{2} \text { Moderator }_{i t}+\Sigma \text { Control }_{i t}+\mu_{i}+\varepsilon_{i t} \\
& \mathrm{ROA}_{\mathrm{it}}=\theta_{0}+\theta_{1} \text { COVID-19t }+\theta_{2} \text { Moderator }_{i \mathrm{t}}+\theta_{3} \text { COVID-19 } * \text { Moderator }_{\mathrm{it}} \\
& +\Sigma \text { Control }_{i t}+\mu_{\mathrm{i}}+\varepsilon_{\mathrm{it}} \\
& \text { Salesgro }_{i t}=\lambda_{0}+\lambda_{1} \text { COVID-19 }_{\mathrm{t}}+\lambda_{2} \text { Moderator }_{\mathrm{it}}+\Sigma \text { Control }_{\mathrm{it}}+\mu_{\mathrm{i}}+\varepsilon_{\mathrm{it}} \\
& \text { Salesgro }_{i t}=\lambda_{0}+\lambda_{1} \text { COVID-19 }_{\mathrm{t}}+\lambda_{2} \text { Moderator }_{\mathrm{it}}+\lambda_{3} \text { COVID-19 } * \text { Moderator }_{\mathrm{it}} \\
& +\Sigma \text { Control }_{i t}+\mu_{\mathrm{i}}+\varepsilon_{\mathrm{it}}
\end{aligned}
$$

Moderators represent the moderating variables. Control is the control variable for firm-level characteristics, including enterprise size (Size), asset-liability ratio (Lev), capital concentration (CD), working capital ratio (Working CR), inventory turnover rate (Itr), flow ratio $(\mathrm{CR})$, etc. $\mu$ i represents individual fixed effects used to eliminate corporate features that do not change over time. Model (4) adds the interaction term of COVID-19 and corporate governance structure in model (3). If $\theta 3$ is significant in model (4), this shows that the different enterprise governance structures will have an impact of COVID-19 on the ROA. Similarly, model (6) adds the interaction term of COVID-19 and enterprise governance structure in model (5). If $\lambda 3$ is significant in model (6), it shows that the different enterprise governance structures will affect the impact of COVID-19 on the growth rate of total operating revenue.

\section{Empirical Results}

\subsection{Propensity Score Matching-Difference in Differences' Empirical Results}

The COVID-19 outbreak at the end of 2019 had a wider impact on China. To control the spread of COVID-19, China adopted relatively strict quarantine and travel restrictions. With the control of the epidemic and the gradual resumption of work and production, other industries gradually resumed production and operation, but the degree of tourism operation recovery is low, declining with more operating performance than other industries. In this study, tourism enterprises and others more affected by the COVID-19 pandemic 
are divided into treatment and control groups. To reduce the estimation bias of the DID method due to sample selection bias, the samples were PSM-matched first.

As shown in Table 2, there is a significant difference in the effect of the new crown pneumonia epidemic before propensity score matching on the return on total assets (ROA), and the growth rate of total operating revenue (Salesgro) of firms. The average treatment effect test after PSM (nearest neighbor matching) shows that the ATT value corresponding to ROA after matching is -2.14 , and the ATT value corresponding to Salesgro is -3.43 , indicating that the average treatment effect is significant, and there is still a significant difference between the treatment and control groups after matching. This means that the impact of COVID-19 on the business performance of tourism enterprises is greater than that on enterprises in other industries impact.

Table 2. Average treatment effect table.

\begin{tabular}{ccccccc}
\hline Variable & Sample & Treated & Controls & Difference & S.E. & T-Statistics \\
\hline ROA & Unmatched & 0.022 & 0.042 & -0.020 & 0.003 & -6.08 \\
& ATT & 0.022 & 0.033 & -0.010 & 0.004 & -2.14 \\
Salesgro & Unmatched & -0.384 & -0.032 & -0.352 & 0.104 & -3.38 \\
& ATT & -0.387 & -0.060 & -0.326 & 0.095 & -3.43
\end{tabular}

Note: ROA and Salesgro represent return on total assets and growth rate of total operating revenue, respectively.

The reliability of the propensity score matching estimates was further measured using the balance hypothesis test. The results are shown in Table 3, from which it can be seen that the absolute values of the standardized deviations of all the matched variables after matching decreased substantially, the standardized deviations of all the matched variables after matching decreased substantially, and the standardized deviations after matching were all within the range of less than $10 \%$, indicating that the matching results were better. Moreover, the T-test results of all matching variables were no longer significant, indicating that there was no significant systematic difference between the treatment and control groups after matching, ensuring the reliability of the subsequent difference-in-difference results. Regarding the matching effect of the treatment and control groups, kernel density function curves before and after propensity score matching were also plotted in this study for comparative analysis. Figure 1 shows that, before the propensity score was matched, the treatment group was unbalanced, the probability density distribution of the propensity score values between both groups is significantly different, and there is selection bias between the samples of the treatment and control groups. Figure 2 shows that, after completing the nearest neighbor matching, the nuclear density curves of the treatment and control groups are very similar. The probability kernel distribution of the two groups tends to be balanced, and the difference between the treatment and control groups decrease significantly, indicating that the main characteristics of the two groups of cities after matching were close, and the selective error of the samples is controlled.

An important prerequisite hypothesis for valid difference-in-difference estimates is that the treatment and control groups have a parallel trend before the event impact [59] and consistency in operating performance between treatment and control enterprises in the absence of a specific public event shock. The COVID-19 outbreak at the end of 2019 first had a large impact on Chinese enterprises and had a strong exogenous nature. China's strictest epidemic control policy to control the spread of the epidemic has almost stalled the production and operations of most enterprises. In 2020, various industries gradually began to resume work and production, but epidemic prevention and control have not been relaxed. At the same time, the entry-exit quarantine policy and the overseas pandemic are still severe, resulting in no significant improvement in Chinese companies' operating performance. Strong external public events make the study satisfy the premise of parallel trends. 
Table 3. Results of the sample propensity score matching equilibrium test.

\begin{tabular}{cccccccc}
\hline & Unmatched & \multicolumn{2}{c}{ Mean } & \multicolumn{3}{c}{ \%Reduct } & \multicolumn{2}{c}{-Test } \\
\hline Variable & Matched & Treated & Control & \%Bias & Bias & t & $\boldsymbol{p}>\mathbf{t}$ \\
\hline \multirow{2}{*}{ WorkingCR } & $\mathrm{U}$ & 0.209 & 0.237 & -13.4 & & -1.63 & 0.103 \\
\multirow{2}{*}{ Lev } & $\mathrm{M}$ & 0.211 & 0.225 & -6.9 & 48.6 & -0.60 & 0.551 \\
& $\mathrm{U}$ & 0.438 & 0.427 & 5.6 & & 0.71 & 0.481 \\
Gro & $\mathrm{M}$ & 0.437 & 0.430 & 3.5 & 38.1 & 0.28 & 0.776 \\
& $\mathrm{U}$ & 0.028 & 0.111 & -48.9 & & -5.55 & 0.000 \\
LnFixed & $\mathrm{M}$ & 0.028 & 0.039 & -6.4 & 86.9 & -0.71 & 0.479 \\
& $\mathrm{U}$ & 19.573 & 20.409 & -57.0 & & -6.96 & 0.000 \\
Itr & $\mathrm{M}$ & 19.583 & 19.539 & 3.0 & 94.8 & 0.27 & 0.789 \\
& $\mathrm{U}$ & 15.874 & 7.3532 & 61.6 & & 10.16 & 0.000 \\
& $\mathrm{M}$ & 15.731 & 15.446 & 2.1 & 96.7 & 0.150 .882 & 0.882
\end{tabular}

Note: U: The treated group and control group before matching methods. M: The treated group and control group after matching methods. WorkingCR, Lev, Gro, LnFixed and Itr represent working capital ratio, asset-liability ratio, total assets growth rate, fixed assets scale and inventory turnover rate, respectively.

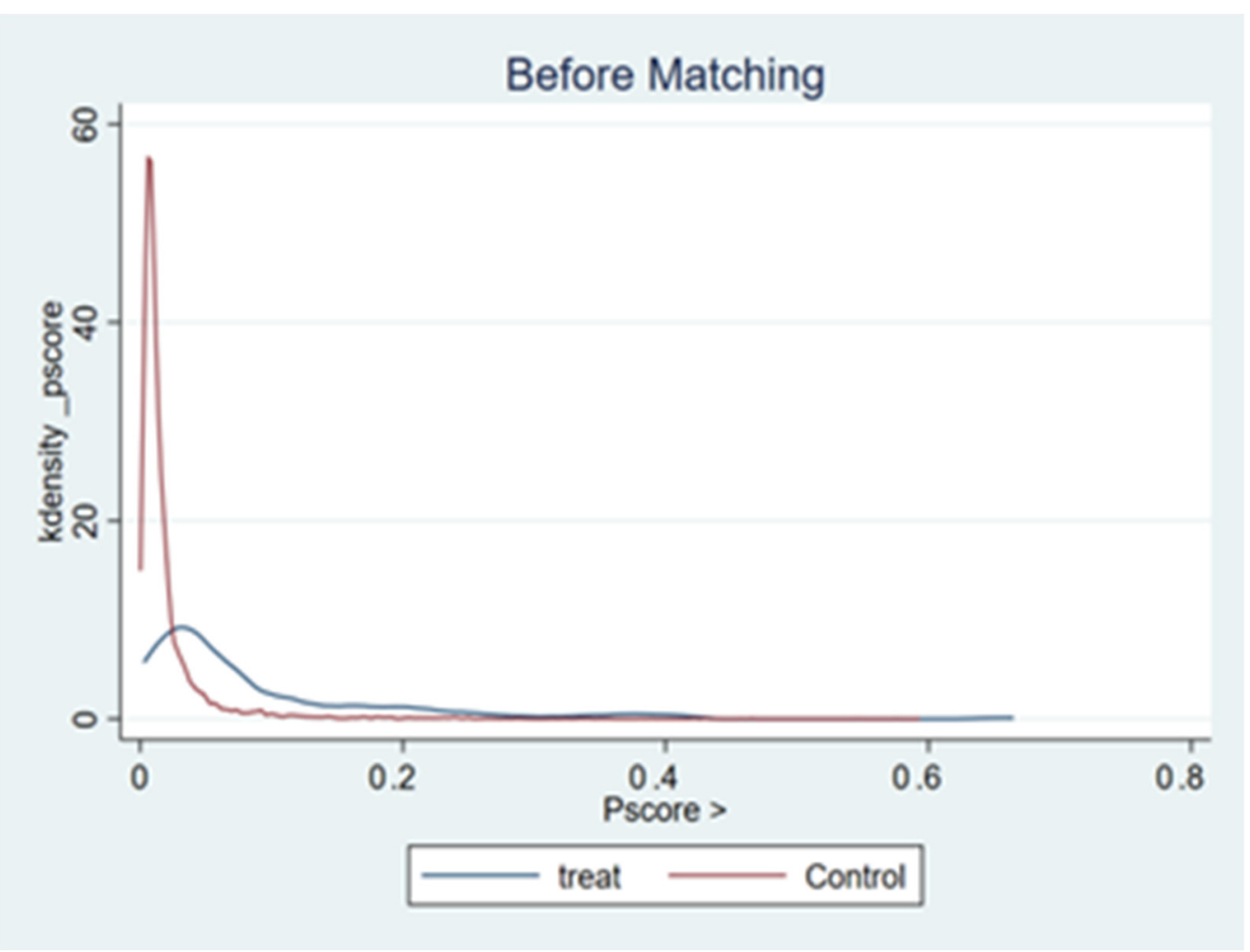

Figure 1. Pre-matching Propensity Scores. 


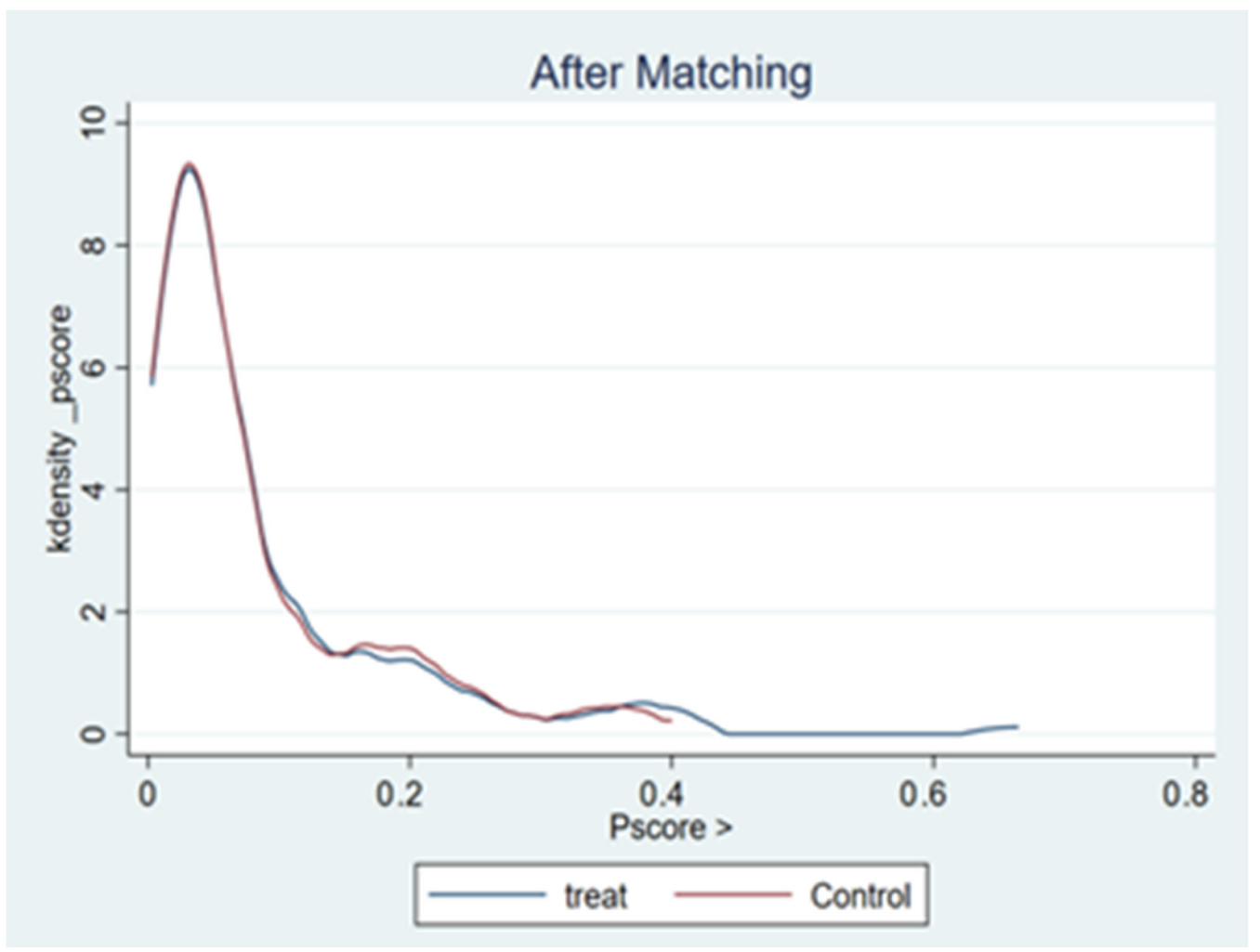

Figure 2. After Matching Propensity Scores.

Based on the matching propensity scores, a control group with similar characteristics to the treatment group was obtained, in which difference-in-difference estimates were performed to test the impact of the COVID-19 outbreak on the operating performance of tourism enterprises. Regression analysis was performed using a fixed-effect model, and the specific regression results are presented in Table 4 . The coefficient of the interaction term Treat ${ }^{*}$ COVID-19 on ROA was -0.012 , and passed the $5 \%$ significance test, showing that the occurrence of the COVID-19 pandemic caused a more significant decline in the return on total assets in tourism than in other industries, supporting the hypothesis of H1a. The coefficient of the interaction term Treat ${ }^{*}$ COVID-19 on Salesgro was -0.449 , and passed the $1 \%$ significance test, showing that the occurrence of the COVID-19 pandemic caused a more significant decline in the growth rate of total operating revenue in tourism than in other industries, supporting the hypothesis of $\mathrm{H} 1 \mathrm{~b}$. This paper concludes that, after the outbreak of the COVID-19 pandemic, the government has taken a series of epidemic control measures, which largely restricted the residents' travel and cross-regional activities; for personnel aggregation and contact control, the development of the tourism industry, represented by accommodation, catering, commercial services, tourism, and cultural entertainment, is more seriously affected than other industries, and tourism consumption demand and supply are simultaneously reduced at the same time. In addition, the operation of tourism is based on cross-regional personnel flow and contact experience. It is difficult for an extensive non-contact online model to reverse the situation for the development of tourism. 
Table 4. Regression results of the difference-in-difference model.

\begin{tabular}{|c|c|c|}
\hline Variables & $\begin{array}{c}\text { (1) } \\
\text { ROA }\end{array}$ & $\begin{array}{c}(2) \\
\text { Salesgro }\end{array}$ \\
\hline Treat*COVID-19 & $\begin{array}{c}-0.012 \text { ** } \\
(-2.21)\end{array}$ & $\begin{array}{c}-0.499^{* * *} \\
(-3.87)\end{array}$ \\
\hline Size & $\begin{array}{c}0.008^{* * * *} \\
(3.35)\end{array}$ & $\begin{array}{c}0.105 * \\
(1.79)\end{array}$ \\
\hline WorkingCR & $\begin{array}{c}0.032 * * \\
(2.30)\end{array}$ & $\begin{array}{l}-0.268 \\
(-0.84)\end{array}$ \\
\hline Lev & $\begin{array}{c}-0.071^{* * *} \\
(-4.73)\end{array}$ & $\begin{array}{l}-0.622 * \\
(-1.77)\end{array}$ \\
\hline Gro & $\begin{array}{c}0.116^{* * *} \\
(7.17)\end{array}$ & $\begin{array}{c}1.576^{* * *} \\
(4.17)\end{array}$ \\
\hline LnFixed & $\begin{array}{l}0.003 \\
(1.41)\end{array}$ & $\begin{array}{l}-0.007 \\
(-0.17)\end{array}$ \\
\hline Itr & $\begin{array}{l}0.000 \\
(0.26)\end{array}$ & $\begin{array}{c}-0.026^{* * *} \\
(-3.58)\end{array}$ \\
\hline $\mathrm{CD}$ & $\begin{array}{c}-0.005^{* * *} \\
(-3.16)\end{array}$ & $\begin{array}{c}-0.234^{* * *} \\
(-5.89)\end{array}$ \\
\hline Constant & $\begin{array}{c}-0.178^{* * *} \\
(-4.01)\end{array}$ & $\begin{array}{l}-1.164 \\
(-1.13)\end{array}$ \\
\hline Industry controls & yes & yes \\
\hline$R^{2}$ & 0.442 & 0.278 \\
\hline Adjusted- $R^{2}$ & 0.424 & 0.254 \\
\hline $\begin{array}{l}\text { Note: } \mathrm{N}=287 \text {. Unstandard } \\
* p<0.1 \text {. Treat represents dur } \\
\text { dummy variable that the year } \\
\text { Itr, and CD represent return } \\
\text { capital ratio, asset-liability ra } \\
\text { concentration, respectively. }\end{array}$ & $\begin{array}{l}\text { rted with t-s } \\
\text { rism enterp } \\
2019 \text { is } 0 . R C \\
\text { th rate of to } \\
\text { th rate, fixec }\end{array}$ & $\begin{array}{l}{ }^{* * *} p<0.01 \\
\text { e } 0 . \text { COVID- } \\
\text { kingCR, Lev, } \\
\text { enterprise } \mathrm{s} \\
\text { turnover rat }\end{array}$ \\
\hline
\end{tabular}

\subsection{Testing the Moderating Role of Corporate Governance Structures}

Tourism listed company means: first, the main business is related to tourism for at least two consecutive years; second, the revenue of tourism business accounts for the largest revenue of the year, and the public issue of shares according to the law and the shares issued by it are approved to be listed and traded on the stock exchange. The latest guidelines on industry classification of listed companies by the China Securities Regulatory Commission in 2012 clearly stipulates the classification principles and methods of listed companies in China. The Guideline on Industry Classification of Listed Companies includes and classifies enterprises according to their main business income. The enterprise category is related to the business involved, with the largest, or more than average operating income being the corresponding enterprise category, which reclassifies the tourism industry into accommodation and catering (H61, H62), business services (L72), public facilities management (N78), and culture, sports, and entertainment (R86, R87). In this study, a total of 103 tourism firms are screened for the period 2019-2020, according to the above principles.

\subsubsection{Descriptive Statistics and Correlation}

According to the descriptive statistics in Table 5, the mean value of return on total assets (Roa) of enterprises is 0 , the maximum value is 0.1 , and the minimum value is -0.178 , indicating that the return on total assets of tourism enterprises has generally been low since the COVID-19 pandemic. The mean value of the proxy variable for corporate growth capacity total revenue growth rate (Salesgro) is -0.191 , the median value is -0.003 , the maximum value is 0.193 , and the minimum value is -1.204 , indicating that tourism firms have a negative level of total revenue growth and poor corporate growth capacity. The mean value of the nature of enterprise equity (Soe) is 0.447 and the median value is 0 , indicating that there are slightly more non-state enterprises than state enterprises 
in the tourism industry. The standard deviations for executive compensation incentives (Top3pay), board size (Board), and supervisory board size (Supervisory) are 0.618, 1.136, and 0.758 , respectively, indicating that there are some differences in governance structures among firms.

Table 5. Descriptive statistics.

\begin{tabular}{ccccccc}
\hline Variable & $\mathbf{N}$ & Mean & Median & SD & Min & Max \\
\hline ROA & 103 & 0.000 & 0.018 & 0.0830 & -0.178 & 0.100 \\
Salesgro & 103 & -0.191 & -0.003 & 0.432 & -1.204 & 0.193 \\
COVID-19 & 103 & 0.301 & 0.000 & 0.461 & 0.000 & 1.000 \\
Soe & 103 & 0.447 & 0.000 & 0.500 & 0.000 & 1.000 \\
Top3pay & 103 & 14.930 & 14.750 & 0.618 & 14.160 & 16.060 \\
Board & 103 & 8.456 & 9.000 & 1.136 & 7.000 & 10.000 \\
Supervisory & 103 & 3.398 & 3.000 & 0.758 & 3.000 & 5.000 \\
Size & 103 & 22.420 & 22.320 & 1.036 & 20.870 & 24.140 \\
Lev & 103 & 0.419 & 0.442 & 0.187 & 0.134 & 0.697 \\
CD & 103 & 2.961 & 2.205 & 2.052 & 0.731 & 6.749 \\
Age & 103 & 20.940 & 21.000 & 4.962 & 13.000 & 28.000 \\
Itr & 103 & 48.220 & 9.784 & 81.160 & 0.841 & 250.100 \\
CR & 103 & 0.559 & 0.585 & 0.199 & 0.244 & 0.861 \\
WorkingCR & 103 & 0.211 & 0.219 & 0.196 & -0.087 & 0.550 \\
\hline
\end{tabular}

Note: ROA, Salesgro, Top3pay, Board, Supervisory, Size, Lev, CD, Age, Itr, CR and WorkingCR represent return on total assets, growth rate of total operating revenue, compensation of the top 3 executives, number of board of directors, number of supervisory boards, enterprise size, asset-liability ratio, capital intensity, company age, inventory turnover rate, current ratio and working capital ratio, respectively. COVID-19 represents dummy variable that the year 2020 is 1 and the year 2019 is 0 . Soe is dummy variable that state-owned enterprise is 1 and non-state-owned enterprise is 0 .

Table 6 is the Pearson's correlation coefficient table with the main variable. Through the table data results, the correlation coefficient between the independent variable COVID-19 pandemic and dependent variables return on total assets (ROA) and total enterprise operating revenue growth rate (Salesgro) are negative and passed the significance test, which can initially verify the correctness of the hypothesis proposed in the theoretical context.

Table 6. Correlation matrix.

\begin{tabular}{|c|c|c|c|c|c|c|c|c|c|c|c|c|c|c|}
\hline Variable & 1 & 2 & 3 & 4 & 5 & 6 & 7 & 8 & 9 & 10 & 11 & 12 & 13 & 14 \\
\hline 1. Roa & 1.000 & & & & & & & & & & & & & \\
\hline 2. Salesgro & $0.582 * * *$ & 1.000 & & & & & & & & & & & & \\
\hline 3. COVID-19 & -0.115 * & $-0.251 * *$ & 1.000 & & & & & & & & & & & \\
\hline 4. Size & $0.203 * *$ & 0.100 & -0.030 & 1.000 & & & & & & & & & & \\
\hline 5. Lev & $-0.308 * * *$ & -0.003 & 0.099 & 0.206 ** & 1.000 & & & & & & & & & \\
\hline 6. CD & $-0.245 * *$ & $-0.393 * * *$ & 0.062 & 0.182 * & -0.046 & 1.000 & & & & & & & & \\
\hline 7. Age & 0.090 & -0.040 & 0.065 & 0.023 & -0.099 & $0.172^{*}$ & 1.000 & & & & & & & \\
\hline 8. Itr & 0.109 & 0.120 & 0.052 & 0.035 & -0.031 & $-0.355 * * *$ & $0.212 * *$ & 1.000 & & & & & & \\
\hline 9. $\mathrm{CR}$ & 0.083 & 0.149 & 0.010 & $-0.289 * * *$ & 0.042 & $-0.516 * * *$ & $-0.285^{* * *}$ & 0.088 & 1.000 & & & & & \\
\hline 10. WorkingCR & $0.343^{* * *}$ & 0.107 & -0.054 & -0.268 *** & $-0.633^{* * *}$ & $-0.255 * * *$ & -0.055 & 0.040 & $0.633 * * *$ & 1.000 & & & & \\
\hline 11. Soe & $0.224 * *$ & $0.199 * *$ & -0.036 & $0.252 * *$ & 0.021 & -0.014 & $0.244^{* *}$ & -0.125 & -0.120 & -0.094 & 1.000 & & & \\
\hline 12. Board & 0.130 & 0.085 & -0.021 & 0.179 * & 0.113 & 0.129 & $0.199 * *$ & 0.035 & $-0.268 * * *$ & $-0.265 * * *$ & $0.415^{* * *}$ & 1.000 & & \\
\hline 13. Supervisory & 0.035 & 0.148 & -0.066 & $0.170 *$ & 0.110 & $0.214 * *$ & $0.305^{* * *}$ & 0.046 & -0.214 ** & -0.168 * & $0.458^{* * * *}$ & $0.345 * * *$ & 1.000 & \\
\hline 14. Тор3pay & $0.290^{* * *}$ & $0.248 * *$ & 0.074 & $0.389 * * *$ & 0.058 & $-0.256 * * *$ & $-0.296^{* * *}$ & -0.017 & 0.128 & 0.090 & -0.061 & 0.029 & $-0.224 * *$ & 1.000 \\
\hline
\end{tabular}

Note: $\mathrm{N}=103 .{ }^{* * *} p<0.01,{ }^{* *} p<0.05,{ }^{*} p<0.1$. ROA, Salesgro, Top3pay, Board, Supervisory, Size, Lev, CD, Age, Itr, CR and WorkingCR represent return on total assets, growth rate of total operating revenue, compensation of the top 3 executives, number of board of directors, number of supervisory boards, enterprise size, asset-liability ratio, capital intensity, company age, inventory turnover rate, current ratio and working capital ratio, respectively. COVID-19 represents dummy variable that the year 2020 is 1 and the year 2019 is 0 . Soe is dummy variable that state-owned enterprise is 1 and non-state-owned enterprise is 0 .

\subsubsection{Regression Result Analysis of the Moderating Effect}

Previous PSM-DID estimates show that the COVID-19 pandemic has a greater negative impact on the operating performance of tourism. However, with respect to different tourism firms, differential corporate governance structures affect them differently in the face of the same external environmental conditions $[2,60]$. Therefore, this study examines the moderating effect of different corporate governance variables on the decline in business performance of tourism enterprises due to the impact of the COVID-19 pandemic from four 
corporate governance perspectives: the nature of corporate equity, executive compensation incentives, board characteristics, and regulation for a total of four proxy variables.

Moderating Effect of Corporate Governance Structure on the Return on Total Assets of Firms Affected by the Impact of COVID-19

$\mathrm{ROA}$, the return on total assets, is used as a proxy variable for firm profitability. Table 7 reports the regression results for the different corporate governance moderating variables.

Table 7. Moderating effect of corporate governance structure on the impact of COVID-19 pandemic on the return on total assets of enterprises (Dependent variable $=$ ROA).

\begin{tabular}{|c|c|c|c|c|c|c|c|c|}
\hline Variables & (1) & (2) & (3) & (4) & (5) & (6) & (7) & (8) \\
\hline COVID-19 & $\begin{array}{c}-0.014^{* *} \\
(-2.29)\end{array}$ & $\begin{array}{c}-0.015^{* *} \\
(-2.49)\end{array}$ & $\begin{array}{c}-0.014^{* *} \\
(-2.11)\end{array}$ & $\begin{array}{l}-0.021 * \\
(-1.80)\end{array}$ & $\begin{array}{l}-0.014 \text { * } \\
(-1.93)\end{array}$ & $\begin{array}{c}-0.015^{* *} \\
(-2.12)\end{array}$ & $\begin{array}{c}-0.019 * * \\
(-2.17)\end{array}$ & $\begin{array}{l}-0.029 * \\
(-1.79)\end{array}$ \\
\hline Soe & $\begin{array}{c}0.013^{* *} \\
(2.16)\end{array}$ & $\begin{array}{l}0.010 \\
(1.57)\end{array}$ & & & & & & \\
\hline Soe*COVID-19 & & $\begin{array}{l}-0.023 * \\
(-1.90)\end{array}$ & & & & & & \\
\hline Top3pay & & & $\begin{array}{l}0.013 * \\
(1.69)\end{array}$ & $\begin{array}{l}0.010 \\
(0.77)\end{array}$ & & & & \\
\hline Top3pay*COVID-19 & & & & $\begin{array}{l}0.027 \text { * } \\
(1.71)\end{array}$ & & & & \\
\hline Board & & & & & $\begin{array}{l}0.007^{*} \\
(1.69)\end{array}$ & $\begin{array}{l}0.006 \\
(1.65)\end{array}$ & & \\
\hline Board*COVID-19 & & & & & & $\begin{array}{c}-0.013^{* *} \\
(-2.54)\end{array}$ & & \\
\hline Supervisory & & & & & & & $\begin{array}{l}0.010 \\
(0.90)\end{array}$ & $\begin{array}{l}-0.002 \\
(-0.14)\end{array}$ \\
\hline Supervisory*COVID-19 & & & & & & & & $\begin{array}{l}-0.061 \\
(-1.63)\end{array}$ \\
\hline Size & $\begin{array}{l}0.010 \\
(1.62)\end{array}$ & $\begin{array}{l}0.007 \\
(1.15)\end{array}$ & $\begin{array}{c}0.009 * \\
(1.70)\end{array}$ & $\begin{array}{l}0.008 \\
(0.83)\end{array}$ & $\begin{array}{l}0.010 * \\
(1.68)\end{array}$ & $\begin{array}{l}0.009 \\
(1.52)\end{array}$ & $\begin{array}{l}0.009 \\
(1.54)\end{array}$ & $\begin{array}{l}0.008 \\
(0.78)\end{array}$ \\
\hline Lev & $\begin{array}{l}-0.032 \\
(-0.96)\end{array}$ & $\begin{array}{l}-0.036 \\
(-1.08)\end{array}$ & $\begin{array}{l}-0.066 \text { * } \\
(-1.73)\end{array}$ & $\begin{array}{l}-0.054 \\
(-0.85)\end{array}$ & $\begin{array}{l}-0.031 \\
(-0.80)\end{array}$ & $\begin{array}{l}-0.027 \\
(-0.74)\end{array}$ & $\begin{array}{l}-0.003 \\
(-0.06)\end{array}$ & $\begin{array}{l}-0.131 \\
(-1.44)\end{array}$ \\
\hline $\mathrm{CD}$ & $\begin{array}{c}-0.012 \text { ** } \\
(-2.25)\end{array}$ & $\begin{array}{c}-0.012 \text { ** } \\
(-2.27)\end{array}$ & $\begin{array}{l}-0.003 \\
(-1.05)\end{array}$ & $\begin{array}{l}-0.003 \\
(-0.76)\end{array}$ & $\begin{array}{l}-0.006 * \\
(-1.85)\end{array}$ & $\begin{array}{l}-0.005 \\
(-1.50)\end{array}$ & $\begin{array}{l}-0.005 \\
(-1.27)\end{array}$ & $\begin{array}{l}-0.003 \\
(-0.58)\end{array}$ \\
\hline Age & $\begin{array}{l}0.001 \\
(0.51)\end{array}$ & $\begin{array}{l}0.001 \\
(0.71)\end{array}$ & $\begin{array}{l}0.000 \\
(0.35)\end{array}$ & $\begin{array}{l}0.000 \\
(0.22)\end{array}$ & $\begin{array}{l}-0.000 \\
(-0.19)\end{array}$ & $\begin{array}{l}-0.000 \\
(-0.30)\end{array}$ & $\begin{array}{l}-0.000 \\
(-0.36)\end{array}$ & $\begin{array}{l}-0.001 \\
(-0.64)\end{array}$ \\
\hline Itr & $\begin{array}{l}-0.000 \\
(-0.49)\end{array}$ & $\begin{array}{l}-0.000 \\
(-0.68)\end{array}$ & $\begin{array}{l}0.000 \\
(0.03)\end{array}$ & $\begin{array}{l}0.000 \\
(0.22)\end{array}$ & $\begin{array}{l}-0.000 \\
(-0.59)\end{array}$ & $\begin{array}{l}-0.000 \\
(-0.13)\end{array}$ & $\begin{array}{l}-0.000 \\
(-0.24)\end{array}$ & $\begin{array}{l}0.000 \\
(0.79)\end{array}$ \\
\hline CR & $\begin{array}{c}-0.101^{* * *} \\
(-2.69)\end{array}$ & $\begin{array}{c}-0.096 \text { ** } \\
(-2.54)\end{array}$ & $\begin{array}{l}-0.025 \\
(-0.59)\end{array}$ & $\begin{array}{l}-0.076 \\
(-1.09)\end{array}$ & $\begin{array}{l}-0.082 * \\
(-1.88)\end{array}$ & $\begin{array}{l}-0.077 * \\
(-1.82)\end{array}$ & $\begin{array}{l}-0.132 \text { ** } \\
(-2.62)\end{array}$ & $\begin{array}{c}-0.019 \\
0.008\end{array}$ \\
\hline WorkingCR & $\begin{array}{c}0.145^{* * *} \\
(3.05)\end{array}$ & $\begin{array}{c}0.129 * * * \\
(2.65)\end{array}$ & $\begin{array}{c}0.077 \\
(1.43)\end{array}$ & $\begin{array}{l}0.159 * \\
(1.81)\end{array}$ & $\begin{array}{c}0.162 * * * \\
(2.97)\end{array}$ & $\begin{array}{c}0.155^{* * *} \\
(2.93)\end{array}$ & $\begin{array}{c}0.200 * * * \\
(3.14)\end{array}$ & $\begin{array}{c}(0.78) \\
-0.131\end{array}$ \\
\hline Constant & $\begin{array}{l}-0.160 \\
(-1.16)\end{array}$ & $\begin{array}{l}-0.195 \\
(-1.37)\end{array}$ & $\begin{array}{c}-0.392 * * * \\
(-3.07)\end{array}$ & $\begin{array}{l}-0.422 * \\
(-1.93)\end{array}$ & $\begin{array}{c}-0.300 * * * \\
(-2.67)\end{array}$ & $\begin{array}{c}-0.293^{* * *} \\
(-2.69)\end{array}$ & $\begin{array}{l}-0.163 \\
(-1.26)\end{array}$ & $\begin{array}{l}-0.341 \text { * } \\
(-1.90)\end{array}$ \\
\hline Industry controls & Yes & Yes & Yes & Yes & Yes & Yes & Yes & Yes \\
\hline$R^{2}$ & 0.533 & 0.556 & 0.559 & 0.525 & 0.541 & 0.573 & 0.693 & 0.530 \\
\hline Adjusted- $R^{2}$ & 0.465 & 0.480 & 0.483 & 0.430 & 0.468 & 0.500 & 0.645 & 0.449 \\
\hline
\end{tabular}

Note: $\mathrm{N}=103$. Unstandardized values are reported with t-statistics in parentheses. ${ }^{* *} p<0.01,{ }^{* *} p<0.05,{ }^{*} p<0.1$. ROA, Top3pay, Board, Supervisory, Size, Lev, CD, Age, Itr, CR and WorkingCR represent return on total assets, compensation of the top 3 executives, number of board of directors, number of supervisory board, enterprise size, asset-liability ratio, capital intensity, company age, inventory turnover rate, current ratio, and working capital ratio, respectively. COVID-19 represents dummy variable that the year 2020 is 1 and the year 2019 is 0 . Soe is dummy variable that state-owned enterprise is 1 and non-state-owned enterprise is 0 .

From the perspective of enterprise equity nature, when enterprise equity nature (Soe) is taken as the moderating variable, the COVID-19 coefficient in column 2 is -0.015 , and passes the significance test of $5 \%$; the interaction item Soe ${ }^{*}$ COVID-19 coefficient is -0.023 and passes the significance test of $10 \%$. This shows that compared with non-state-owned tourism enterprises, there is less decline in the return on total assets given the impact of the COVID-19 pandemic, supporting the hypothesis of H2a.

From the perspective of executive compensation incentive, when the executive compensation incentive (Top3pay) was used as the moderating variable, the COVID-19 coefficient in column 4 was -0.021 , passed the $10 \%$ significance test, interaction term 
Top3pay*COVID-19 coefficient was 0.027 , and passed the $10 \%$ significance test, indicating that tourism enterprises with higher executive compensation incentives decreased less in the return on total assets given the impact of the COVID-19 pandemic, supporting the hypothesis of H3a.

Analysis from the perspective of the structure of the board of directors and supervisory board: when the board size (Board) is the moderating variable, the coefficient of COVID-19 in column 6 is -0.015 and passes the $5 \%$ significance test, and the coefficient of the interaction term Board ${ }^{*}$ COVID-19 is -0.015 and passes the $5 \%$ significance test. This indicates that the larger the board size of tourism companies in the impact of the COVID-19 pandemic, the greater the corporate return on total assets, supporting hypothesis H4a. When the size of the supervisory board supervisory is a moderating variable, the regression coefficient of supervisory on return on total assets (ROA) in column 8 is not significant, and the coefficient of COVID-19 in model 4 is 0.030 and passes the $10 \%$ significance test, but the coefficient of the interaction term Supervisory ${ }^{*}$ COVID-19 is -0.061 , which does not pass the significance test. This indicates that the size of the supervisory board of tourism enterprises does not have a moderating effect on the decrease in the return on total assets of enterprises given the impact of the new crown pneumonia epidemic, and hypothesis H5a is supported.

Moderating Effect of Corporate Governance Structure on the Growth Rate of Total Operating Revenue of Firms Affected by the Impact of COVID-19

The growth rate of total operating revenue (Salesgro) is used as a proxy variable for firm growth capability. The regression results in Table 8 are as follows.

Table 8. The moderating effect of corporate governance variables on the impact of COVID-19 pandemic to reduce the growth ability of enterprises (Dependent variable $=$ sSalesgrow).

\begin{tabular}{|c|c|c|c|c|c|c|c|c|}
\hline Variables & (1) & (2) & (3) & (4) & (5) & (6) & (7) & (8) \\
\hline COVID-19 & $\begin{array}{c}-0.093 * * \\
(-2.32)\end{array}$ & $\begin{array}{c}-0.093 \text { ** } \\
(-2.29)\end{array}$ & $\begin{array}{c}-0.430 * * * \\
(-3.75)\end{array}$ & $\begin{array}{c}-0.452 * * * \\
(-4.08)\end{array}$ & $\begin{array}{c}-0.098 * * \\
(-2.29)\end{array}$ & $\begin{array}{c}-0.102 * * \\
(-2.44)\end{array}$ & $\begin{array}{c}-0.153 \text { ** } \\
(-2.25)\end{array}$ & $\begin{array}{c}-0.157 \text { ** } \\
(-2.41)\end{array}$ \\
\hline Soe & $\begin{array}{c}0.075^{*} \\
(1.69)\end{array}$ & $\begin{array}{l}0.067 \\
(1.48)\end{array}$ & & & & & & \\
\hline Soe*COVID-19 & & $\begin{array}{l}-0.131 \\
(-1.68)\end{array}$ & & & & & & \\
\hline Top3pay & & & $\begin{array}{c}0.168 * \\
(1.77)\end{array}$ & $\begin{array}{c}0.166^{*} \\
(1.82)\end{array}$ & & & & \\
\hline Top3pay*COVID-19 & & & & $\begin{array}{c}0.422^{* * *} \\
(2.81)\end{array}$ & & & & \\
\hline Board & & & & & $\begin{array}{l}0.034 \\
(1.52)\end{array}$ & $\begin{array}{l}0.033 \\
(1.54)\end{array}$ & & \\
\hline Board*COVID-19 & & & & & & $\begin{array}{c}-0.076^{* *} \\
(-2.61)\end{array}$ & & \\
\hline Supervisory & & & & & & & $\begin{array}{c}0.112 * * \\
(2.35)\end{array}$ & $\begin{array}{c}0.092 * * \\
(2.11)\end{array}$ \\
\hline Supervisory*COVID-19 & & & & & & & & $\begin{array}{l}-0.148 \\
(-1.63)\end{array}$ \\
\hline Size & $\begin{array}{l}0.036 \\
(1.04)\end{array}$ & $\begin{array}{l}0.032 \\
(0.96)\end{array}$ & $\begin{array}{l}0.092 \\
(1.17)\end{array}$ & $\begin{array}{l}0.075 \\
(0.99)\end{array}$ & $\begin{array}{l}0.045 \\
(1.59)\end{array}$ & $\begin{array}{l}0.043 \\
(1.54)\end{array}$ & $\begin{array}{l}0.051 \\
(1.04)\end{array}$ & $\begin{array}{l}0.054 \\
(1.62)\end{array}$ \\
\hline Lev & $\begin{array}{l}0.163 \\
(0.79)\end{array}$ & $\begin{array}{l}0.139 \\
(0.64)\end{array}$ & $\begin{array}{l}-0.383 \\
(-0.51)\end{array}$ & $\begin{array}{l}-0.355 \\
(-0.49)\end{array}$ & $\begin{array}{l}0.106 \\
(0.46)\end{array}$ & $\begin{array}{l}0.128 \\
(0.58)\end{array}$ & $\begin{array}{l}-0.263 \\
(-0.65)\end{array}$ & $\begin{array}{l}-0.389 \\
(-1.01)\end{array}$ \\
\hline CD & $\begin{array}{c}-0.048^{* *} \\
(-2.50)\end{array}$ & $\begin{array}{c}-0.041 * * \\
(-2.32)\end{array}$ & $\begin{array}{l}-0.064^{* *} \\
(-2.11)\end{array}$ & $\begin{array}{c}-0.061^{* *} \\
(-2.08)\end{array}$ & $\begin{array}{c}-0.051^{* * *} \\
(-2.85)\end{array}$ & $\begin{array}{c}-0.045^{* *} \\
(-2.58)\end{array}$ & $\begin{array}{c}-0.043^{* *} \\
(-2.25)\end{array}$ & $\begin{array}{c}-0.041 \text { ** } \\
(-2.41)\end{array}$ \\
\hline Age & $\begin{array}{l}-0.004 \\
(-0.68)\end{array}$ & $\begin{array}{l}-0.003 \\
(-0.66)\end{array}$ & $\begin{array}{l}0.006 \\
(0.52)\end{array}$ & $\begin{array}{l}0.008 \\
(0.68)\end{array}$ & $\begin{array}{l}-0.002 \\
(-0.39)\end{array}$ & $\begin{array}{l}-0.003 \\
(-0.51)\end{array}$ & $\begin{array}{l}-0.008 \\
(-1.05)\end{array}$ & $\begin{array}{l}-0.008 \\
(-1.02)\end{array}$ \\
\hline Itr & $\begin{array}{l}0.001 \\
(0.52)\end{array}$ & $\begin{array}{l}0.000 \\
(0.45)\end{array}$ & $\begin{array}{l}-0.000 \\
(-0.53)\end{array}$ & $\begin{array}{l}-0.000 \\
(-0.71)\end{array}$ & $\begin{array}{l}-0.000 \\
(-0.17)\end{array}$ & $\begin{array}{l}0.000 \\
(0.28)\end{array}$ & $\begin{array}{l}-0.000 \\
(-0.12)\end{array}$ & $\begin{array}{l}-0.000 \\
(-0.27)\end{array}$ \\
\hline CR & $\begin{array}{l}-0.167 \\
(-0.70)\end{array}$ & $\begin{array}{l}-0.086 \\
(-0.35)\end{array}$ & $\begin{array}{l}-0.114 \\
(-0.14)\end{array}$ & $\begin{array}{l}-0.174 \\
(-0.23)\end{array}$ & $\begin{array}{l}-0.071 \\
(-0.28)\end{array}$ & $\begin{array}{l}-0.052 \\
(-0.21)\end{array}$ & $\begin{array}{l}0.162 \\
(0.37)\end{array}$ & $\begin{array}{l}0.288 \\
(0.67)\end{array}$ \\
\hline
\end{tabular}


Table 8. Cont.

\begin{tabular}{|c|c|c|c|c|c|c|c|c|}
\hline Variables & (1) & (2) & (3) & (4) & (5) & (6) & (7) & (8) \\
\hline \multirow[t]{2}{*}{ WorkingCR } & 0.377 & 0.268 & 0.049 & 0.071 & 0.325 & 0.297 & -0.130 & -0.243 \\
\hline & (1.29) & $(0.89)$ & $(0.05)$ & $(0.08)$ & (1.03) & $(0.97)$ & $(-0.25)$ & $(-0.47)$ \\
\hline \multirow[t]{2}{*}{ Constant } & -0.696 & -0.691 & $-4.122 * *$ & $-3.996 * *$ & $-1.243 *$ & $-1.204 *$ & -1.290 & -1.267 \\
\hline & $(-0.95)$ & $(-1.05)$ & $(-2.60)$ & $(-2.61)$ & $(-1.82)$ & $(-1.81)$ & $(-1.59)$ & $(-1.61)$ \\
\hline Industry controls & Yes & Yes & Yes & Yes & Yes & Yes & Yes & Yes \\
\hline$R^{2}$ & 0.311 & 0.317 & 0.366 & 0.419 & 0.303 & 0.353 & 0.317 & 0.332 \\
\hline Adjusted- $R^{2}$ & 0.202 & 0.199 & 0.265 & 0.318 & 0.201 & 0.250 & 0.199 & 0.225 \\
\hline
\end{tabular}

Note: $\mathrm{N}=103$. Unstandardized values are reported with t-statistics in parentheses. ${ }^{* *} p<0.01,{ }^{* *} p<0.05,{ }^{*} p<0.1$. Salesgro, Top3pay, Board, Supervisory, Size, Lev, CD, Age, Itr, CR and WorkingCR represent growth rate of total operating revenue, compensation of the top 3 executives, number of board of directors, number of supervisory board, enterprise size, asset-liability ratio, capital intensity, company age, inventory turnover rate, current ratio, and working capital ratio, respectively. COVID-19 represents dummy variable that the year 2020 is 1 and the year 2019 is 0 . Soe is dummy variable that state-owned enterprise is 1 and non-state-owned enterprise is 0.

From the perspective of enterprise equity, when the enterprise equity nature (Soe) is taken as the moderating variable, the COVID-19 coefficient in column 2 is -0.093 and passes the significance test of $5 \%$, the coefficient of the interaction term Soe*COVID-19 is -0.131 , and passes the $10 \%$ significance test, which shows that, compared with non-stateowned tourism enterprises, state-owned tourism enterprises have a lower growth rate given the impact of the COVID-19 pandemic, supporting the hypothesis of $\mathrm{H} 2 \mathrm{~b}$.

From the perspective of executive compensation incentives, when the executive compensation incentive Top3pay is used as the moderating variable, the coefficient of COVID-19 in column 4 is -0.452 , the coefficient of interaction term Top3pay*COVID-19 is 0.422 and passes the $1 \%$ significance test, which shows that tourism enterprises with higher executive compensation incentives decreased less in the growth rate of total operating revenue of enterprises given the impact of the COVID-19 pandemic, supporting the hypothesis of $\mathrm{H} 3 \mathrm{~b}$.

From the perspective of the structure of the board of directors and supervisors: when the board size (Board) is the moderating variable, the coefficient of COVID-19 in column 6 is -0.102 and passes the $5 \%$ significance test, and the coefficient of the interaction term Board ${ }^{*}$ COVID-19 is -0.076 , and passes the $5 \%$ significance test, indicating a larger board size of tourism enterprises in the impact of the new crown pneumonia epidemic. The coefficient of COVID-19 in column 8 is -0.157 when Supervisory Board size is used as the moderating variable, and it passes the $5 \%$ significance test, but the coefficient of the interaction term Supervisory*COVID-19 is -0.148 , which does not pass the significance test. This indicates that the size of the supervisory board of tourism enterprises does not have a moderating role in the decline of the growth rate of gross operating income of enterprises given the impact of the new crown pneumonia epidemic, and hypothesis $\mathrm{H} 5 \mathrm{~b}$ is supported.

\section{Conclusion and Implications}

\subsection{Conclusion}

The outbreak of COVID-19 has had a strong impact on many industries at home and abroad, and the economies of all countries around the world have been contained. To effectively cut off the transmission of the virus, labor-intensive industries stopped production and residents restricted the flow, causing China's economy to press the pause button. The development of tourism requires a cross-regional and international flow of people, and the COVID-19 outbreak bears the brunt. Taking a sample of non-financial listed companies in China's Shanghai and Shenzhen from 2019 to 2020, the results of this study empirically examined through the PSM-DID model show that the impact of the COVID-19 pandemic has produced a more severe decline in both the return on total assets and the growth rate of total operating revenue for tourism companies than for other industries, and hypotheses H1a and H1b are supported. Furthermore, tourism enterprises are taken as a sample to examine the moderating role of different enterprise governance structure characteristics on the declining operating performance of tourism enterprises due to the COVID-19 pandemic, and the results show that the corporate governance structure 
characteristics play a heterogeneous moderating role. That is, given the impact of the COVID-19 pandemic, the return on total assets and the growth rate of total operating revenue of state-owned enterprises decreased less, and hypotheses $\mathrm{H} 2 \mathrm{a}$ and $\mathrm{H} 2 \mathrm{~b}$ are supported. The tourism firms with higher executive compensation incentives had less decline in the return on total assets and the growth rate of total operating revenue, and hypotheses $\mathrm{H} 3 \mathrm{a}$ and $\mathrm{H} 3 \mathrm{~b}$ are supported. The larger the board size, the greater the decline in the return on total assets and the growth rate of total operating revenue in the tourism enterprises, hypotheses $\mathrm{H} 4 \mathrm{a}$ and $\mathrm{H} 4 \mathrm{~b}$ are supported, but the size of the supervisory board does not moderate the decrease in the total return on assets and the rate of growth of total operating revenue of tourism enterprises; hypotheses $\mathrm{H} 5 \mathrm{a}$ and $\mathrm{H} 5 \mathrm{~b}$ are supported (see Table 9).

Table 9. Summary of hypothesis testing results.

\begin{tabular}{|c|c|c|}
\hline & Hypotheses & Results \\
\hline $\mathrm{H} 1$ & $\begin{array}{l}\text { The impact of COVID-19 has caused a more serious decline in tourism corporate performance } \\
\text { than in other industries. }\end{array}$ & Supported \\
\hline H1a & $\begin{array}{c}\text { The impact of COVID-19 has caused a more serious decline in the return on total assets of } \\
\text { tourism enterprises than in other industries. }\end{array}$ & Supported \\
\hline $\mathrm{H} 1 \mathrm{~b}$ & $\begin{array}{l}\text { The impact of COVID-19 has caused a greater decline in the growth rate of tourism enterprises } \\
\text { than in other industries. }\end{array}$ & Supported \\
\hline $\mathrm{H} 2$ & $\begin{array}{l}\text { Compared with non-state-owned tourism enterprises, state-owned enterprises (SOEs) have } \\
\text { decreased less in corporate performance given the impact of COVID-19. }\end{array}$ & Supported \\
\hline $\mathrm{H} 2 \mathrm{a}$ & $\begin{array}{c}\text { Compared with non-state-owned tourism enterprises, SOEs have decreased less in corporate } \\
\text { return on total assets given the impact of COVID-19. }\end{array}$ & Supported \\
\hline $\mathrm{H} 2 \mathrm{~b}$ & $\begin{array}{l}\text { Compared with non-state-owned tourism enterprises, SOEs have declined less in the growth } \\
\text { rates of total operating revenue given COVID-19. }\end{array}$ & Supported \\
\hline $\mathrm{H} 3$ & $\begin{array}{c}\text { Tourism enterprises with higher levels of compensation incentives have less decline in corporate } \\
\text { performance given the impact of COVID-19. }\end{array}$ & Supported \\
\hline $\mathrm{H} 3 \mathrm{a}$ & $\begin{array}{c}\text { Tourism enterprises with higher levels of compensation incentives have less decline in their } \\
\text { return on total assets given COVID-19. }\end{array}$ & Supported \\
\hline $\mathrm{H} 3 \mathrm{~b}$ & $\begin{array}{c}\text { Tourism enterprises with higher levels of compensation incentives have less decline in the } \\
\text { growth rates of total operating revenue given COVID-19. }\end{array}$ & Supported \\
\hline $\mathrm{H} 4$ & $\begin{array}{c}\text { The smaller the board size of tourism enterprises, the less the decline in corporate performance } \\
\text { given COVID-19. }\end{array}$ & Supported \\
\hline $\mathrm{H} 4 \mathrm{a}$ & $\begin{array}{c}\text { The smaller the board size of tourism enterprises, the less the decline in their return on total } \\
\text { assets given COVID-19. }\end{array}$ & Supported \\
\hline $\mathrm{H} 4 \mathrm{~b}$ & $\begin{array}{l}\text { The smaller the board size of tourism enterprises, the less the decline in the growth rates of total } \\
\text { operating revenue given COVID-19. }\end{array}$ & Supported \\
\hline H5 & $\begin{array}{c}\text { There is no impact of the size of the board of supervisors of tourism enterprises on corporate } \\
\text { performance given the impact of COVID-19. }\end{array}$ & Supported \\
\hline $\mathrm{H} 5 \mathrm{a}$ & $\begin{array}{l}\text { There is no impact of the size of the board of supervisors of tourism enterprises on the firm 's } \\
\text { total return on assets given the impact of COVID-19. }\end{array}$ & Supported \\
\hline $\mathrm{H} 5 \mathrm{~b}$ & $\begin{array}{c}\text { There is no impact of the size of the board of supervisors of tourism enterprises on the growth } \\
\text { rates of total operating revenue given COVID-19. }\end{array}$ & Supported \\
\hline
\end{tabular}

\subsection{Implications}

Based on the above research results, we believe that tourism is a highly sensitive industry in the external environment. After the outbreak of COVID-19, major travel agencies and travel companies suspended operations and returned passenger booking fees in full, resulting in a shortage of capital and turnover pressure for many tourism companies. With the effective control of the epidemic, some tourism industries have resumed operations, but the recovery of the tourism market has been slow, due to factors such as low consumer demand for tourism and restrictions on the flow of people to scenic spots. In addition, there are still uncertainties and instability in the COVID-19 pandemic, and the normal prevention and control measures will continue in the short term. Given the influence of COVID-19, epidemic control policies, working capital shortages, poor 
capital turnover, increased operating costs, market depression, and other factors cause the performance of tourism enterprises to decline more seriously than in other industries.

Different corporate governance structure characteristics play a heterogeneous moderating role in the decline of the operating performance of tourism enterprises due to the COVID-19 epidemic.

Analysis from the enterprise equity nature perspective. The COVID-19 pandemic has caused serious cash flow shortages, high liquidity pressure, slow market recovery, and employee turnover in tourism enterprises. This study argues that in the face of many difficulties caused by COVID-19, state-owned enterprises have a stronger ability to respond to emergencies than non-state-owned enterprises, a more stable economic foundation, smaller financial constraints, and a more stable employee payment level than state-owned enterprises. After the epidemic is gradually controlled and t work and production resumed in an orderly manner, state-owned enterprises can resume operations and reduce losses as soon as possible given the epidemic prevention and control policy. Based on the above conclusions, more policy support should be given and preference should be given at the national level to help tourism enterprises get through the market depression caused by the COVID-19 pandemic. At the enterprise level, to avoid the excessive concentration of equity, appropriate decentralized equity can help to enhance the enthusiasm and synergy of non-state shareholders to participate in enterprise operation and management, so that enterprises can explore a new business model given the background of the normal epidemic to improve enterprise performance.

Analysis from the executive compensation incentive perspective. Many studies point out that executive incentive strategy is one of the main ways to solve the problem of modern enterprise agencies, which can promote the formation of interest alliances between executives and shareholders, thus improving enterprise operating performance. This study argues that the epidemic has caused the income of the entire tourism industry to decline, and most tourism enterprises are in a loss-making situation. Compensation incentives as effective short-term incentives can motivate managers faster, stimulate executives' willingness to take risks, and bring into play the incentive effect of active innovation of executives, which is conducive to tourism enterprises' efforts to reduce the decline of operating performance in the short-term market environment of depression. Based on this, the compensation incentive is a current reward that effectively combines executive income with corporate value, but an excessive compensation incentive level may lead to the short-term aggressive behavior of senior executives, posing risks to the future development of the enterprise. Tourism enterprises should reasonably formulate executive compensation incentive plans, appropriately improve the executive compensation incentive level at a comparable level in the industry, and motivate executives to actively take risks to actively explore diversified business methods when the enterprise is losing money and the market is poor, thus improving the operating performance of the enterprise.

Analysis from the board of directors and supervisors' characteristics perspective-the results of the study show that the larger the board size, the greater the decline in the return on total assets and the growth rate of total operating revenue in the tourism industry given the impact of the COVID-19 outbreak. In contrast, the size of the supervisory boards of tourism firms did not have a moderating effect on the decline in the rate of return on total assets and the growth rate of gross operating revenues given the impact of the COVID-19 pandemic. This is because tourism has a high sensitivity to the external environment, and changes in the political, economic, natural, and social environments all impact the development of tourism. Douglas et al. [61] pointed out that given the current normalization of COVID-19, consumer social gatherings and activities must meet the practice of social distancing. Consumers will select organic products and travel services that meet healthy social distancing, relative concealment, and social responsibility will be more selected by consumers [62,63]. This requires tourism enterprise managers to have efficient market sensitivity and decision-making ability to adapt to changes in the market environment. The larger board size of tourism firms can make their decision-making relatively slow 
and create a lag in responding to market information. Especially in the context of the normalization of COVID-19, in the face of many changeable and uncontrollable factors, if tourism enterprises cannot make timely and effective decisions on environmental and policy changes, it will directly affect the performance level of enterprises. From the statistical results, we can see that the supervisory boards of tourism listed companies in the sample are between three and five people. Although the board of supervisors, as the internal regulatory agency of enterprises, plays a supervisory role in the senior executives of enterprises, it cannot effectively improve the performance of enterprises. Based on this, given the influence of the normalization of the epidemic for tourism enterprises, on the basis of ensuring complete structure and complete ability, a streamlined and efficient board structure is more likely to improve the efficiency and cohesion of decision-making teams, so enterprises should actively seek ways out in the complex and changeable external environment, and reduce the decline in enterprise performance.

There are certain limitations in this study. The limited number of samples is mainly due to the small number of listed tourism companies and the lack of availability of financial data. Although the sample selected in this study represents the basic situation of Chinese tourism enterprises, there are still some small- and medium-sized enterprises in the market. More reliable results are obtained in future studies. At the same time, the impact of the COVID-19 pandemic on tourism enterprises can only be measured until 2020 from the perspective of data acquisition, which limits the selection of the sample range. In future research, the development of tourism can be analyzed in the post-epidemic era. Lastly, our data constraints do not leave us with any way to compare the impact of COVID-19 pandemic on firms across fairly different industries. Therefore, future research could take a closer look at the unique effect of the COVID-19 pandemic on firm performance across different industries.

Author Contributions: Data curation, Y.G.; Methodology and draft, S.J.; Review and editing, S.X. All authors have read and agreed to the published version of the manuscript.

Funding: This research received no external funding.

Institutional Review Board Statement: Not applicable.

Informed Consent Statement: Not applicable.

Data Availability Statement: Not applicable.

Conflicts of Interest: The authors declare no conflict of interest.

\section{References}

1. Baggio, R. The Science of complexity in the tourism domain: Aa perspective article. Tour. Rev. 2019, 75, 16-19. [CrossRef]

2. Cornelissen, S. The Global Tourism System; Routledge: London, UK, 2017; p. 206.

3. UNWTO. Impact Assessment of the COVID-19 Outbreak on International Tourism. Available online: www.unwto.org/impactassessment-of-the-covid-19-outbreak-on-international-tourism (accessed on 12 May 2020).

4. UNWTO. 100\% of Global Destinations Now Have COVID-19 Travel Restrictions, UNWTO Reports. Available online: www. unwto.org/news / covid-19-travel-restrictions (accessed on 15 May 2020).

5. Bhagat, S.; Bolton, B. Director Ownership, Governance, and Performance. J. Financ. Quant. Anal. 2013, 48, 105-135. [CrossRef]

6. Lars, H.H.; Sofia, J.; Denis, S. Is Corporate Governance in China Related to Performance Persistence? J. Bus. Ethics 2016, 134, 575-592.

7. Oehmichen, J.; Schrapp, S.; Wolff, M. Who Needs Experts Most? Board Industry Expertise and Strategic Change-A Contingency Perspective. Strateg. Manag. J. 2016, 38, 645-656. [CrossRef]

8. Yeh, C.M. Does board governance matter for foreign institutional investors to invest in listed tourism firms? Tour. Manag. 2018, 68, 66-78. [CrossRef]

9. Guillet, B.D.; Mattila, A.S. A descriptive examination of corporate governance in the hospitality industry. Int. J. Hosp. Manag. 2010, 29, 677-684. [CrossRef]

10. Peng, H.; Zhang, J.; Zhong, S.; Li, P. Corporate governance, technical efficiency and financial performance: Evidence from Chinese listed tourism firms. J. Hosp. Tour. Manag. 2021, 48, 163-173. [CrossRef]

11. Andersson, T.D.; Getz, D. Tourism as a mixed industry: Differences between private, public and not-for-profit festivals. Tour. Manag. 2009, 30, 847-856. [CrossRef] 
12. Ntim, C.G.; Lindop, S.; Osei, K.A.; Thomas, D.A. Osei and Dennis A. Thomas Source, Executive Compensation, Corporate Governance and Corporate Performance. Manag. Decis. Econ. 2015, 36, 67-96. [CrossRef]

13. Ozdemir, O.; Upneja, A. Board structure and CEO compensation: Evidence from U.S. lodging industry. Int. J. Hosp. Manag. 2012, 31, 856-863. [CrossRef]

14. Wang, H.D.; Yue, H.; Zhang, X. Research on the Relationship between Corporate Governance Structure and Firm PerformanceBased on The Perspective of Total Factor Productivity of Firms. Shanghai Econ. Res. 2019, 4, 17-27.

15. The World Economic Situation and Prospects as of mid-2021, United Nations Department of Economic and Social Affairs, May 2021. 2021. Available online: https://www.un.org/development/desa/dpad/publication/world-economic-situation-andprospects-as-of-mid-2021/ (accessed on 11 May 2021).

16. Statistical Bulletin on National Economic and Social Development of the People's Republic of China in 2020, National Bureau of Statistics, February 2021. 2021. Available online: https: / / baijiahao.baidu.com/s?id=1692906851582420925\&wfr=spider\&for=pc (accessed on 1 May 2021). (In Chinese).

17. Nicola, M.; Alsafi, Z.; Sohrabi, C.; Kerwan, A.; Al-Jabir, A.; Iosifidis, C.; Agha, M.; Agha, R. The socio-economic implications of the coronavirus and COVID-19 pandemic: A review. Int. J. Surg. 2020, 78, 185-193. [CrossRef] [PubMed]

18. Carolina, A.; Dani, B.; Manel, P.E.; Saida, P.R. Modelling the Crisis Management and Impacts of 21st Century Disruptive Events in Tourism: The Case of the COVID-19 Pandemic. Tour. Rev. 2021, 76, 929-941.

19. Core, J.E.; Holthausen, R.W.; Larcker, D.F. Corporate governance, chief executive officer compensation, and firm performance. J. Financ. Econ. 1999, 51, 371-406. [CrossRef]

20. Claessens, S. Corporate Governance and Development. World Bank Res. Obs. 2006, 21, 91-122. [CrossRef]

21. Bebchuk, L.A.; Cohen, A.; Wang, C.C. Learning and the disappearing association between governance and returns. J. Financ. Econ. 2013, 108, 323-348. [CrossRef]

22. Borisova, G.; Brockman, P.; Salas, J.M.; Zagorchev, A. Government ownership and corporate governance: Evidence from the EU. J. Bank Financ. 2012, 36, 2917-2934. [CrossRef]

23. Tang, J.; Tang, Z.; Cowden, B.J. Exploring the Relationship between Entrepreneurial Orientation, CEO Dual Values, and SME Performance in State-Owned vs. Nonstate-Owned Enterprises in China. Entrep. Theory Pr. 2017, 41, 883-908. [CrossRef]

24. Lyu, X. Eequity Structure, Executive Incentive and Listed Company Governance Efficiency-based on Heterogenous Stochastic Boundary Model. Manag. Rev. 2015, 6, 128.

25. Jiang, L.; Cao, Y.; Liao, D. Research on the Relationship between Governance Structure and Investment Efficiency-analysis Based on State-owned and Private Listed Companies. Res. Financ. Econ. 2015, 10, 104-110.

26. Ritchie, B.W.; Jiang, Y. A review of research on tourism risk, crisis and disaster management: Launching the annals of tourism research curated collection on tourism risk, crisis and disaster management. Ann. Tour. Res. 2019, 79, 102812. [CrossRef]

27. Assaf, A.; Scuderi, R. COVID-19 and the recovery of the tourism industry. Tour. Econ. 2020, 26, 731-733. [CrossRef]

28. Brouder, P.; Teoh, S.; Salazar, N.B.; Mostafanezhad, M.; Pung, J.M.; Lapointe, D.; Higgins-Desbiolles, F.; Haywood, M.; Hall, C.M.; Clausen, H.B. Reflections and discussions: Tourism matters in the new normal post COVID-19. Tour. Geogr. 2020, 22, 735-746. [CrossRef]

29. Victor, H. Work and Motivation; John Wiley \& Sons: New York, NY, USA, 1994.

30. Polat, R.; Nisar, T.M. Financial Crisis and Changes in Firm Governance, Corporate Structure, and Boundaries. Manag. Decis. Econ. 2013, 34, 363-378. [CrossRef]

31. Dechow, P.M. Asymmetric Sensitivity of CEO Cash Compensation oo Stock Returns: A Discussion. J. Account. Econ. 2006, 42, 193-202. [CrossRef]

32. Jackson, S.B.; Lopez, T.J.; Reitenga, A.L. Accounting fundamentals and CEO bonus compensation. J. Account. Public Policy 2008, 27, 374-393. [CrossRef]

33. Schneider, P.J. The Managerial Power Theory of Executive Compensation. J. Financ. Serv. Prof. 2013, 5, 17-22.

34. Sheikh, M.F.; Shah, S.Z.A.; Akbar, S. Firm performance, corporate governance and executive compensation in Pakistan. Appl. Econ. 2018, 50, 2012-2027. [CrossRef]

35. Kato, T.; Long, C. Executive Compensation, Firm Performance, and Corporate Governance in China: Evidence from Firms Listed in the Shanghai and Shenzhen Stock Exchanges. Econ. Dev. Cult. Chang. 2006, 54, 945-983. [CrossRef]

36. Al-Najjar, B. Corporate governance and CEO pay: Evidence from UK Travel and Leisure listed firms. Tour. Manag. 2017, 60, 9-14. [CrossRef]

37. Coles, J.; Daniel, N.; Naveen, L. Boards: Does one size fit all? J. Financ. Econ. 2008, 87, 329-356. [CrossRef]

38. Dalton, C.M.; Dalton, D.R. Boards of Directors: Utilizing Empirical Evidence in Developing Practical Prescriptions. Br. J. Manag. 2005, 16, S91-S97. [CrossRef]

39. Lipton, M.; Lorsch, J.W.A. Modest Proposal for Improved Corporate Governance. Bus. Lawyer 1992, 48, 59-77.

40. Jensen, M.C. The Modern Industrial Revolution, Exit, and the Failure of Internal Control System. J. Financ. 1993, 48, 831-880. [CrossRef]

41. Yermack, D. Higher Market Valuation for Firms with a Small Board of Directors. J. Financ. Econ. 1996, 40, 185-211. [CrossRef]

42. Nguyen, P.; Rahman, N.; Tong, A.; Zhao, R. Board size and firm value: Evidence from Australia. J. Manag. Gov. 2016, 20, 851-873. [CrossRef] 
43. Mark, Y.T.; Kusnadi, Y. Size Really Matters: Further Evidence on the Negative Relationship between Board Size and Firm Value. Pac. Basin Financ. J. 2005, 13, 301-318.

44. De Andres, P.; Azofra, V.; Lopez, F. Corporate Boards in OECD Countries: Size, composition, functioning and effectiveness. Corp. Gov. Int. Rev. 2005, 13, 197-210. [CrossRef]

45. O'Connell, V.; Cramer, N. The relationship between firm performance and board characteristics in Ireland. Eur. Manag. J. 2010, 28, 387-399. [CrossRef]

46. Carpenter, M.A.; Westphal, J.D. The Strategic Context of External Network Ties: Examining the Impact of Director Appointments on Board Involvement in Strategic Decision Making. Acad. Manag. J. 2001, 4, 639-660.

47. Goodstein, J.; Gautam, K.; Boeker, W. The effects of board size and diversity on strategic change. Strat. Manag. J. 1994, 15, 241-250. [CrossRef]

48. Yeh, C.M.; Trejos, B. The influence of governance on tourism firm performance. Curr. Issues Tour. 2013, 18, 299-314. [CrossRef]

49. Li, W.; Wang, S.; Wang, S. Major Shareholders Equity Competition and Board Governance-based on empirical analysis of Chinese listed companies. Comp. Econ. Soc. Syst. 2006, 3, 61-66.

50. Wang, D.; Zhang, H.; Zhang, C.; Li, H. The Impact of Board Governance on Business Performance of Tourism Listed CompaniesAnalysis Based on Unbalanced Panel Data. J. Tour. 2014, 11, 36-44.

51. Utama, C.A.; Utama, S. Board of Commissioners in Corporate Governance, Firm Performance, and Ownership Structure. Int. Res. J. Bus. Stud. 2019, 12, 111-136. [CrossRef]

52. Aluchna, M.; Kaminski, B. Ownership structure and company performance: A panel study from Poland. Balt. J. Manag. 2017, 12, 485-502. [CrossRef]

53. Li, Muchun; Liu, Tingting; Research on the Effectiveness of Governance Structure of Directors of Tourism Listed Companies. J. South China Univ. Technol. (Soc. Sci. Ed.) 2018, 20, 26-38.

54. Jin, Y.; Vonderembse, M.; Ragu-Nathan, T.; Smith, J.T. Exploring relationships among IT-enabled sharing capability, supply chain flexibility, and competitive performance. Int. J. Prod. Econ. 2014, 153, 24-34. [CrossRef]

55. Liu, H.; Wu, S.; Zhong, C.; Liu, Y. The Sustainable Effect of Operational Performance on Financial Benefits: Evidence from Chinese Quality Awards Winners. Sustainability 2020,12, 1966. [CrossRef]

56. Rosenbaum, P.R.; Donald, B.R. The Central Role of the Propensity Score in Observational Studies for Causal Effects. Biometrika 1983, 70, 41-55. [CrossRef]

57. Latorre, M.C.; Yonezawa, H.; Zhou, J. A general equilibrium analysis of FDI growth in Chinese services sectors. China Econ. Rev. 2018, 47, 172-188. [CrossRef]

58. Benzarti, Y.; Harju, J. Using Payroll Tax Variation to Unpack the Black Box of Firm-Level Production. J. Eur. Econ. Assoc. 2021, 19, 2737-2764. [CrossRef]

59. Bertrand, M.; Duflo, E.; Mullainathan, S. How Much Should We Trust Differences-In-Differences Estimates? Q. J. Econ. 2004, 119, 249-275. [CrossRef]

60. Al-Najjar, B. Corporate governance, tourism growth and firm performance: Evidence from publicly listed tourism firms in five Middle Eastern countries. Tour. Manag. 2014, 42, 342-351. [CrossRef]

61. Douglas, M.; Katikireddi, S.V.; Taulbut, M.; McKee, M.; McCartney, G. Mitigating the wider health effects of covid-19 pandemic response. BMJ 2020, 369, m1557. [CrossRef]

62. Everingham, P.; Chassagne, N. Post COVID-19 ecological and social reset: Moving away from capitalist growth models towards tourism as Buen Vivir. Tour. Geogr. 2020, 22, 555-566. [CrossRef]

63. Galvani, A.; Lew, A.A.; Perez, M.S. COVID-19 Is Expanding Global Consciousness and the Sustainability of Travel and Tourism. Tour. Geogr. 2020, 22, 1-10. [CrossRef] 